\title{
Plant Knowledge in the Historia Naturalis Brasiliae (1648): Retentions of Seventeenth-Century Plant Use in Brazil
}

\author{
Mireia Alcantara-Rodriguez ${ }^{*}, 1$, Mariana Françozo ${ }^{1}$, and \\ TINDE VAN ANDEL ${ }^{2,3}$
}

${ }^{1}$ Faculty of Archaeology, Leiden University, Einsteinweg 2, 2333 CC, Leiden, the Netherlands

${ }^{2}$ Clusius chair in History of Botany and Gardens, Leiden University, Darwinweg 2, 2333 CR, Leiden, the

Netherlands

${ }^{3}$ Naturalis Biodiversity Center, PO Box 9517, 2300 RA, Leiden, the Netherlands

*Corresponding author; e-mail: +34644743853m.alcantara.rodriguez@arch.leidenuniv.nl

The Historia Naturalis Brasiliae (HNB, 1648) is the most complete treatise on Brazilian flora and fauna created in the seventeenth century. Scientists Marcgrave and Piso depicted hundreds of plants and described uses, vernacular names, and diseases in Dutch Brazil. We aimed to verify whether these plants are still used similarly, using herbarium vouchers and taxonomic literature to identify the species described in the HNB and reviewing historical and modern ethnobotanical literature to analyze whether the HNB documented specific plants and uses for the northeast region. We highlighted Old World species, as they indicate plant introduction before and during the trans-Atlantic slave trade and exchange of African ethnobotanical knowledge. Of the 378 species found in the HNB, 256 (68\%) were useful, mostly used for healing and food in a similar way (80\%) both in the seventeenth century and in modern Brazil. Only one species (Swartzia pickelii) is endemic to northeast Brazil, while the others are more widely distributed. The HNB includes one of the first reports on African crops in Brazil, such as sesame, okra, and spider plant. This study brings insights on indigenous and African plant knowledge retentions since the creation of the HNB and acknowledges its non-European contributors.

Conhecimento de plantas na Historia Naturalis Brasiliae (1648): retençóes de uso de plantas úteis do século XVII no Brasil Mireia Alcántara Rodríguez, Mariana Françozo, Tinde van Andel

\begin{abstract}
Resumo
O livro Historia Naturalis Brasiliae (HNB, 1648) é o mais completo tratado sobre a flora e fauna brasileiras criado no século XVII. Os cientistas Marcgrave e Piso descreveram centenas de plantas e seus usos, seus nomes vernaculares, bem como doenças no Brasil Holandês. Nosso objetivo foi verificar se as plantas do HNB ainda são usadas de forma semelhante, usando exsicatas de herbários e literatura taxonômica para identificar as espécies descritas no trabalho de Marcgrave e Piso, e revisando literatura etnobotânica histórica e moderna para analisar se o HNB documentou plantas específicas e seus usos para a regiáo nordeste. Destacamos espécies de origem africana, pois sua presença indica a introdução de plantas antes e durante o tráfico transatlântico de escravos e a troca de conhecimento etnobotânico africano. Das 378 espécies encontradas no HNB, 256 (68\%) são úteis, usadas principalmente para cura e alimentação (80\%), tanto no século XVII quanto no Brasil moderno. Apenas uma espécie (Swartzia pickelii) é endêmica no nordeste
\end{abstract}

\footnotetext{
${ }^{1}$ Received 6 November 2018; accepted 1 August 2019; published online 25 October 2019

Electronic supplementary material The online version of this article (https://doi.org/10.1007/s12231-01909469-w) contains supplementary material, which is available to authorized users.
} 
do Brasil, enquanto as outras são mais amplamente distribuídas. O HNB inclui um dos primeiros relatos sobre plantas africanas cultivadas no Brasil, como gergelim, quiabo e planta de aranha. Neste estudo, revelamos a retenção de conhecimento indígena e africano sobre plantas desde a criação do $\mathrm{HNB} e$ reconhecemos o papel crucial de seus contribuintes não europeus.

Key Words: Marcgrave, Piso, medicinal plants, Dutch Brazil, Afro-Brazilians, indigenous knowledge, Tupi.

\section{Introduction}

The Dutch West India Company (WIC) occupied northeastern Brazil from 1630 to 1654 , in search of economic profits from the exploitation of Brazil wood (Caesalpinia echinata (Lam.) Spreng.) and sugarcane (Saccharum officinarum L.) (Mors et al. 2000). The captaincy, modern-day state, of Pernambuco constituted the central point of the Dutch colony in the seventeenth century and was then the greatest sugar producer worldwide (Santos et al. 2010). Dutch Brazil was governed from 1637 to 1644 by Count Johan Maurits of Nassau-Siegen, who assembled a group of scholars and painters to depict the local geography, biodiversity, indigenous population, tropical diseases, and traditional medicine. This group included German naturalist and astronomer Georg Marcgraf, Dutch physician Willem Pies (also known as Marcgrave and Piso), and Dutch painters Frans Post and Albert Eckhout (Souza 2006), among others whose names are still unknown.

Marcgrave explored northeastern Brazil (particularly Pernambuco, Paraíba, and Rio Grande do Norte), where he studied the flora, fauna, geography, meteorology, and astronomy of the territory, while Piso focused more on medicinal plants and local diseases. Dutch artist Frans Post painted Brazilian landscapes, while Albert Eckhout worked on portraits of people in Dutch Brazil and paintings of the fauna and flora of the region. Marcgrave confided to Nassau some dried plant specimens and several manuscripts about Brazilian natural history before leaving to Angola between 1643 and 1644 (Whitehead 1979). Marcgrave's plant specimens and manuscripts were received by geographer and WIC board member Johannes de Laet, who transcribed, edited, and published them in 1648 , together with Piso's writings, in one of the most influential treatises on Brazilian botany, zoology, and medicine: Historia Naturalis Brasiliae (HNB). Marcgrave and Piso's legacy also comprises a second version of the book published by Piso alone, two Portuguese translations, and Marcgrave's bound herbarium, among other artistic and botanical materials (Whitehead and Boeseman 1989).
The HNB is divided into two sections: the first part, De Medicina Brasiliensi, written by Piso and subdivided into four chapters, provides an account of local diseases and Brazilian medicine. Medicinal plants used by the inhabitants of seventeenthcentury Brazil, generally from Pernambuco, are depicted in the last chapter. The second part, Historia Rerum Naturalium, is devoted to Marcgrave's natural history studies. This part is divided into eight chapters: the first three on plants, the next four chapters on fauna, and the last one on ethnology. In addition, four plant drawings are displayed at the end of the book. The plant chapters present descriptions and numerous woodcut images, separated into three subchapters: herbs, plants with fruits, and shrubs and trees.

Johannes de Laet discovered that woodcuts were missing for some plants, so he produced new ones based on the dried specimens collected by Marcgrave that were later included in the bound herbarium, or from dried specimens sent to him by his colleagues residing in Brazil (Gudger 1912). He published the book with many comments, especially about plants (Françozo 2010), and also added several annotations from the works of the Spanish monk and apothecary Francisco Ximenez de Quesada (1615) and the Spanish physician Nicolas Monardes (1574). Ximenez published a book about the nature and herbal medicine of Mexico, based on part of the results of the expeditions by the physician Francisco Hernández in 1570 (Cook and Dupré 2013), while Monardes studied medicinal plants brought to him from the Spanish colonies in the Americas and cultivated in Seville. De Laet compared the plants described by Marcgrave with the ones described by Ximenez and Monardes, and by early modern naturalists, such as Carolus Clusius, Rembert Dodoens, and Garcia da Orta; religious chroniclers, such as Jean de Léry and André Thevet; and explorers, such as Gabriel Soares de Souza (Almeida 2008). The HNB was the earliest and most extensive intellectual product of Natural History that came from the Dutch colonies in the New World, and despite covering a region in the northeast of Brazil, this was interpreted by 
Europeans as an encyclopedia that represented the flora, fauna, and population of the whole country (Françozo 2010).

Marcgrave's chapters in the HNB were translated for the first time from Latin into Portuguese and edited by José Procópio de Magalhães in 1942. Piso's chapters were translated into Portuguese and edited by Alexandre Correia in 1948. Piso's section was extended with a biography of Piso and Marcgrave and several reviews on their work by the Brazilian historian Affonso de E. Taunay. In both the original and translated editions of the HNB, specimens of plants and animals are organized in an index by vernacular names. In the Portuguese edition of 1948 , Correia included the comments of the Brazilian botanist Alberto J. de Sampaio, who added a scientific classification of the plants reported by Marcgrave with local names (História Natural do Brasil, pp. XLVIII-LI). He based this classification mainly on the work of the German botanist Carl Friedrich Philipp von Martius, who studied Marcgrave's herbarium and published, between 1840 and 1906, the Flora Brasiliensis (2005).

The second version of the HNB, entitled De Indiae Utriusque Re Naturali et Medica (IURNM), was published by Piso in 1658. He incorporated Marcgrave's figures and descriptions in his own text but made some botanical mistakes (Andrade-Lima et al. 1977). The 1658 book, organized in three parts and 14 chapters, covers both the Southeast Asian and Northeast Brazilian colonies explored in the seventeenth century by the Dutch. The first part corresponds to Piso's observations and is a review and enlargement of the first version. The second part includes two chapters, which include Marcgrave's annotations on topography and meteorology with his comments about Brazilian customs and languages. The further chapters are taken from the work published in 1642 by Jacob Bontius (Bontius 1642), a Dutch physician who worked for 4 years in the Dutch colony of Batavia, modern-day Jakarta (Albertin 1985).

Marcgrave's botanical collections and notes were sent to the Netherlands in 1646, presumably by the Count of Nassau to De Laet, who published the HNB in 1648, but kept the herbarium containing Marcgrave's specimens (Andrade-Lima et al. 1977). The herbarium was of interest to Ole Worm, a Danish antiquarian and physician at the court of king Frederik III of Denmark, and acquaintance of De Laet. Both scholars shared correspondence about plant material and knowledge that circulated in the Netherlands during the Dutch enterprise in
Brazil. Through the son of Worm, living in the Netherlands, the herbarium was bound and sent to Denmark in 1653, and eventually acquired by Frederik III after Worm's death in 1654, probably because of their shared interest in natural history collections (Romero-Reverón and Arráez-Aybar 2015). Finally, Marcgrave's herbarium was transferred to the Botanical Museum of the University of Copenhagen at the end of the eighteenth century. In the late 1970s, botanists identified 137 species out of the 146 taxa preserved in the book herbarium, 90 of which are also described in the HNB (Andrade-Lima et al. 1977).

This extensive record of Brazilian flora and medicinal plants had a great impact on the European scientific community, being used as a reference for many scholars, from taxonomists to naturalists or chroniclers working in the tropics (Safier 2014). The Swedish naturalist Carl Linnaeus based part of his taxonomy on the species described in the $\mathrm{HNB}$, because he considered the scientific descriptions and illustrations to be of high quality (Whitehead and Boeseman 1989). Linnaeus included many species of Piso and especially Marcgrave in the 10th edition of his Systema Naturae (1758), all validated for scientific purposes with binomial Latin names (Boeseman 1994). Marcgrave and Piso's work was even considered to be one of the most important contributions to the science of Natural History since Aristotle and Pliny the Elder by Gudger (1912). Moreover, the HNB provided a rich source of plant knowledge of native Brazilians, especially of indigenous peoples from the Tupi macro linguistic family, which promoted the introduction of useful plants to Europe. Examples are ipecacuanha root (Carapichea ipecacuahna (Brot.) L.Andersson) and copaiba oil (Copaifera officinalis L.), which are still used for medicinal purposes in Brazil and Europe (Lorenzi and Matos 2008).

Several botanists have attempted to identify the specimens depicted in the HNB and the IURNM, such as Alberto José de Sampaio (Correia 1948), and especially Bento José Pickel (Almeida 2008), but these identifications are often incomplete or outdated according to the new nomenclature system (The Plant List 2013). No detailed overview existed so far on the plant uses in the HNB. Medeiros and Albuquerque (2014) compared the seventeenth-century food plants in the HNB with present-day uses, but they used Pickel's often incorrect taxonomy and did not base their plant identifications on the original sources (HNB, IURNM, Marcgrave herbarium). 
In this paper, we present new identifications of all useful plant species described in the original Latin HNB and IURNM, as well as the specimens in Marcgrave's herbarium. We compared the seventeenth-century plant uses with modern Brazilian uses from recent ethnobotanical literature. By comparing the plant uses in the HNB (compiled in northeastern Brazil) to plant uses in the rest of the country, which is increasingly covered by ethnobotanical surveys, we analyze whether the HNB documented plants and uses specific for the northeast region or represents a more general Brazilian plant use in the 1640s. Since 1648, the natural environment in Brazil has changed due to sugarcane monocultures, deforestation, industrialization, and urbanization (Freyre 1989; Rogers 2010). Indigenous peoples who survived slavery, European diseases, and genocide have often migrated to other areas and merged with other groups in complex processes of transformation, resistance, and ethnogenesis (Langfur 2014; Monteiro 1999; Rodrigues 1994). Therefore, we expect that many plant uses may have changed. Likewise, we anticipate substantial changes in plant use over time because perceptions about health and diseases, plant-based diet, and recipes in the seventeenth century were much different from today (Corrêa 1926-1975). We also expect to find species of African origin in the HNB, as a result of the trans-Atlantic slave trade that started in Pernambuco from circa 1560 by the Portuguese (Eltis and Richardson 2010). To test these hypotheses, we addressed the following questions: Which useful plants are listed in the Historia Naturalis Brasiliae and in De India Utriusque Re Naturali et Medica? Are these plants used in a similar way in recent ethnobotanical literature? Which species described in the HNB are of Old World origin? Through this study, we bring insights on the retentions of indigenous and African plant knowledge since colonial Dutch Brazil.

\section{Materials and Methods}

\section{Source Material}

We used several types of source material to identify the useful plant species described by Marcgrave and Piso (Table 1). We consulted the original Latin edition of the HNB (1648) to check the watercolor woodcuts and the original Latin edition of IURNM (1658) to check for illustrations that do not appear in the 1648 edition, but correspond to plant species described in this first book. We also consulted the Portuguese editions of HNB (Marcgrave 1942 [1648]; Piso 1948 [1648]) to check the woodcuts and the plant descriptions. We identified all useful plant specimens by verifying Pickel's 1949 identifications (Almeida 2008) with Brazilian and other South American collections at the herbarium of Naturalis Biodiversity Center (L) in Leiden, the Netherlands, botanical literature (Lorenzi 1998; Lorenzi and Matos 2008), and the online checklist Flora do Brasil 2020 (2016) for species distributions and vegetation types. We asked several botanists at the Naturalis herbarium to verify our identifications. We checked the latest taxonomic status of each species by using The Plant List (2013). We identified all specimens in Marcgrave's bound herbarium collections by using the South American collections in the herbarium of Copenhagen (C) and the floristic literature. We made digital images of all Marcgrave's original collections and deposited them with the curator, Prof. Dr. Ib Friis. In addition, we studied the plants depicted in the paintings of Albert Eckhout and Frans Post in the National Museum of Denmark in Copenhagen and at the Rijksmuseum in Amsterdam.

\section{Data Analysis}

We organized our data with information on author and date of the consulted source, page number, taxonomical identification of the plant (genus, species, and family), vernacular names (in original spelling), geographic distribution, cultivation state, vegetation type, biomes, and seventeenth-century uses (Electronic Supplementary Material-ESM 1). Subsequently, we searched for modern plant uses for these species in the extensive work of Pio Corrêa (1926-1975), Mors et al. (2000), Schoof (2012), and Lorenzi (1998), Lorenzi and Matos (2008) and additional queries in Google Scholar on specific plant uses in Brazil.

We did not limit this study to the northeast Brazil where Marcgrave and Piso worked because the landscape, and its flora, and inhabitants have changed drastically since the seventeenth century. Many species have disappeared from Pernambuco due to deforestation and conversion of land to agriculture, but these plants are still present in other parts of their distribution range. More importantly, most species in the HNB are commonly found in regions outside the northeast, occur as weeds throughout Brazil, or are widely cultivated by people of different ethnic origins. 


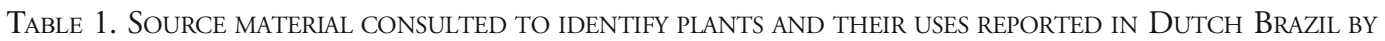
MarCGRAVE AND Piso.

\begin{tabular}{|c|c|c|c|}
\hline$\overline{\text { Title }}$ & Authors and date & Source material & Location \\
\hline $\begin{array}{l}\text { Historia Naturalis Brasiliae } \\
\text { [HNB] }\end{array}$ & $\begin{array}{r}\text { George Marcgrave \& } \\
\text { Willem Piso, } 1648\end{array}$ & $\begin{array}{l}\text { Original Latin book } \\
\text { Digital copy }\end{array}$ & $\begin{array}{l}\text { Naturalis Library, Leiden } \\
\text { https://archive. } \\
\text { org/details/marcgrave }\end{array}$ \\
\hline $\begin{array}{l}\text { De Indiae Utriusque Re } \\
\text { Naturali et Medica [p. 2] }\end{array}$ & Willem Piso, 1658 & Digital copy of Latin book & $\begin{array}{l}\text { Library of NL Tijdschrift voor } \\
\text { Geneeskunde, Amsterdam } \\
\text { https://archive. } \\
\text { org/details/mobot31753002909064 }\end{array}$ \\
\hline Historia Rerum Naturalium & $\begin{array}{l}\text { José Procópio de } \\
\text { Magalhães, } 1942\end{array}$ & $\begin{array}{l}\text { Portuguese translation of } \\
\text { Marcgrave's chapters } \\
\text { (1648) }\end{array}$ & Naturalis Library, Leiden \\
\hline De Medicina Brasiliensi & $\begin{array}{l}\text { Alexandre Correia, } \\
1948\end{array}$ & $\begin{array}{l}\text { Portuguese translation of } \\
\text { Piso's chapters } 1648\end{array}$ & Naturalis Library, Leiden \\
\hline Marcgrave's Herbarium & $\begin{array}{l}\text { Georg Marcgrave, } \\
\text { collected } 1638 \text { to } \\
1643\end{array}$ & $\begin{array}{l}\text { Original bound herbarium } \\
\text { and digital images }\end{array}$ & $\begin{array}{l}\text { Botanical Garden of the University } \\
\text { of Copenhagen, Denmark }\end{array}$ \\
\hline $\begin{array}{l}\text { Still life paintings and landscape } \\
\text { paintings }\end{array}$ & $\begin{array}{l}\text { Albert Eckhout and } \\
\text { Frans Post, } \\
\text { seventeenth century }\end{array}$ & $\begin{array}{l}\text { Original paintings and } \\
\text { iconographic book } \\
\text { (Buvelot et al. 2004) }\end{array}$ & $\begin{array}{l}\text { National Museum of Denmark, } \\
\text { Rijksmuseum Amsterdam }\end{array}$ \\
\hline $\begin{array}{l}\text { Flora do Nordeste do Brasil } \\
\text { segundo Piso e Marcgrave no } \\
\text { século XVII }\end{array}$ & $\begin{array}{l}\text { D. Bento José Pickel, } \\
\text { 1937-1949 }\end{array}$ & $\begin{array}{l}\text { Commemorative edition } \\
\text { (Almeida 2008) }\end{array}$ & $\begin{array}{l}\text { http://www.ufrpe.br/download. } \\
\text { php? endArquivo=noticias } / 4543 \text { _ } \\
\text { florafinal.pdf }\end{array}$ \\
\hline $\begin{array}{l}\text { Marcgrave's Brazilian } \\
\text { Herbarium, collected } \\
\text { 1638-1644 }\end{array}$ & $\begin{array}{l}\text { Andrade-Lima et al. } \\
\quad 1977\end{array}$ & $\begin{array}{l}\text { Article published in } \\
\text { Botanisk Tidsskrift }\end{array}$ & Botanical library Naturalis, Leiden \\
\hline
\end{tabular}

We searched for the distribution data of the useful species described in the HNB and their vegetation type in the online Flora do Brasil 2020 (2016), unless there were obvious errors or misinterpretations in these data. In this case, we used the Bioportal Naturalis (2019), Catalogue of Life: 2008 Annual Checklist (2018), Tropicos (2019), Species Link (2019), and CNC Flora (2012) to look for distribution patterns of herbarium specimens.

We categorized traditional and modern uses in food (including spices and drinks), medicine (including cosmetics), construction, technology (including fibers, ink, paper, illumination, fish poison, tanning, and insecticides), and others (e.g., ornamental, fuel, living fences, shadow plants, erosion control, fodder, and rituals) following Prance et al. (1987). Based on the plant uses in the HNB, we divided medicinal uses in 11 frequently occurring categories: antidotes, purgatives and emetics, sexually transmitted diseases (STDs), diarrhea, wounds, febrifuges, diuretics, dropsy, skin affections, emmenagogues, and antiparasitic. The seventeenthcentury data enriched with similar modern plant uses were transformed into a MS Word file where matching uses were extracted from the literature (ESM 2).

\section{Results}

\section{Comparing HNB Uses to Modern Plant USES IN BRAZIL}

We encountered 391 plant entries in Marcgrave and Piso's books $(1648,1658)$ and Margrave's herbarium. We identified 378 different species, as some species were described several times. Plant entries often included local names, descriptions on plant uses, but not always illustrations. A total of 267 plant entries corresponded to plants used by the native population, enslaved Africans, or European colonizers in seventeenth-century Brazil, while 124 entries corresponded to plants with no uses reported by Marcgrave. The 267 entries of useful species sometimes included plants cited twice or more times and referred to a total of 256 unique useful species validated by the Plant List and the Flora do Brasil 2020 (ESM 1), representing 68\% of the total number of species in Marcgrave and Piso's books $(1648,1658)$. The most species-rich families were Leguminosae (43 species), followed by Arecaceae, Solanaceae, and Myrtaceae (each 11 spp.), and 
Malvaceae, Compositae, Annonaceae, and Cucurbitaceae (each 8 spp.).

When comparing the historic uses with modern plant uses, we found that 204 species $(80 \%$ of the total of useful species) had similar uses in the recent literature to those reported by Marcgrave and Piso in the seventeenth century (ESM 2). We could not find any uses in modern-day Brazil for 15 of the 256 useful plant species in the HNB: Aniseia cernua Moric., Campomanesia dichotoma (O.Berg) Mattos, Clidemia biserrata DC., C. octona (Bonpl.) L.O. Williams, Dioclea marginata Benth., Gnaphalium cf. polycaulon Pers., Lundia virginalis DC., Matelea ganglinosa (Vell.) Rapini, Ouratea caudata Engl., Piper phytolaccifolium Opiz, Rhizophora racemosa G.Mey., Scleria gaertneri Raddi, Tanaecium cyrtanthum (Mart. ex DC.) Bureau \& K.Schum., T. pyramidatum (Rich.) L.G.Lohmann, and Vitex rufescens A.Juss.

In general, the number of useful plant reports per use category in modern Brazil is higher than in the seventeenth century. We observed more species in the categories of medicine, construction, technology, and other. On the contrary, we detected a slight decline in the food category, where 12 species listed as edible in the HNB are currently no longer used for nutritional purposes (Fig. 1). Of the 256 useful species, most plants were used as medicine, both in the seventeenth century (171 species, 67\%) and in modern Brazil (187 spp., 73\%), although 22 medicinal species documented in 1648 seem to have lost their therapeutic use. For example, no medicinal use for Albizia saman (Jacq.) Merr. was found in modern literature, although Piso described it as an "astringent and diuretic plant, which root is used to treat kidney and bladder affections, gonorrhea, syphilis and dropsy . . . to treat eye inflammation" (Piso 1648, p. 80). On the other hand, 44 useful species that were not reported as medicinal in the past are used therapeutically according to contemporary literature. For instance, Marcgrave mentioned that the fruit of Chrysobalanus icaco L. was edible (Marcgrave 1648, p. 77), without mentioning any other use, while this plant was used in the 1930 s as an astringent agent to combat diarrhea, gonorrhea, and leucorrhoea and by women to contract their genitalia to fake virginity (Corrêa 1931).

It is noteworthy that 84 medicinal species documented by Marcgrave and Piso had at least one specific medicinal application in common with the twentieth or twenty-first century; however, the way plants are used has changed substantially over time (Fig. 2). While in the seventeenth century most medicinal species were used to heal ulcers, wounds, and abscesses, modern Brazilians use most of these species as purgative or emetic agents. Another common modern use is diuretics, treatments against STDs, and aphrodisiacs, which were less prevalent in the past. Purgatives, emetics, emmenagogues, and plants to treat fever, intestinal worms, and skin infections are also more reported today than in the past. The use of plants as antipoisons or against dropsy, however, is less common at present. In addition to our medicinal use categories (Fig. 2), other several affections, such as stomachache, bladder and kidney obstructions, and rheumatism, were

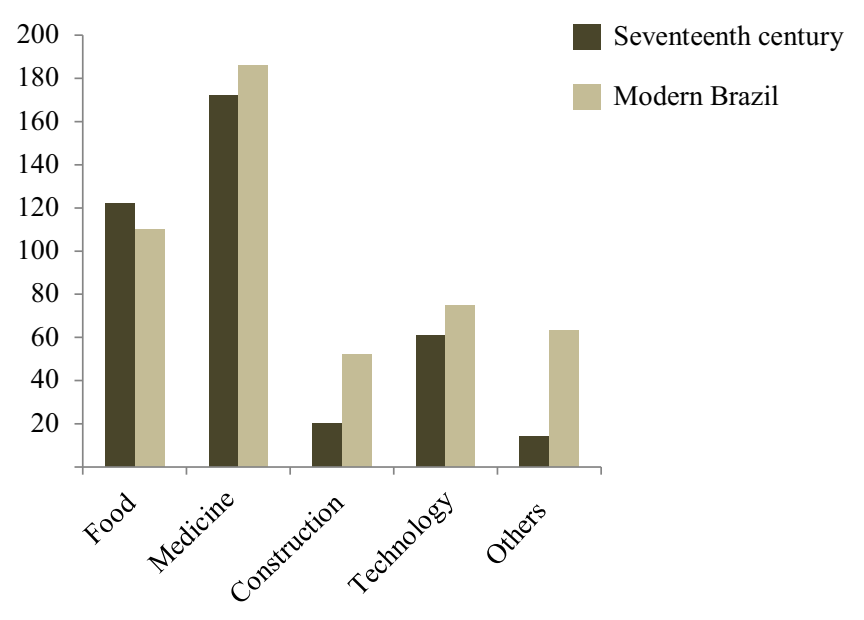

Fig. 1.. Number of species listed by Marcgrave and Piso $(1648,1658)$ for the different use categories and current uses for these species in Brazil. 


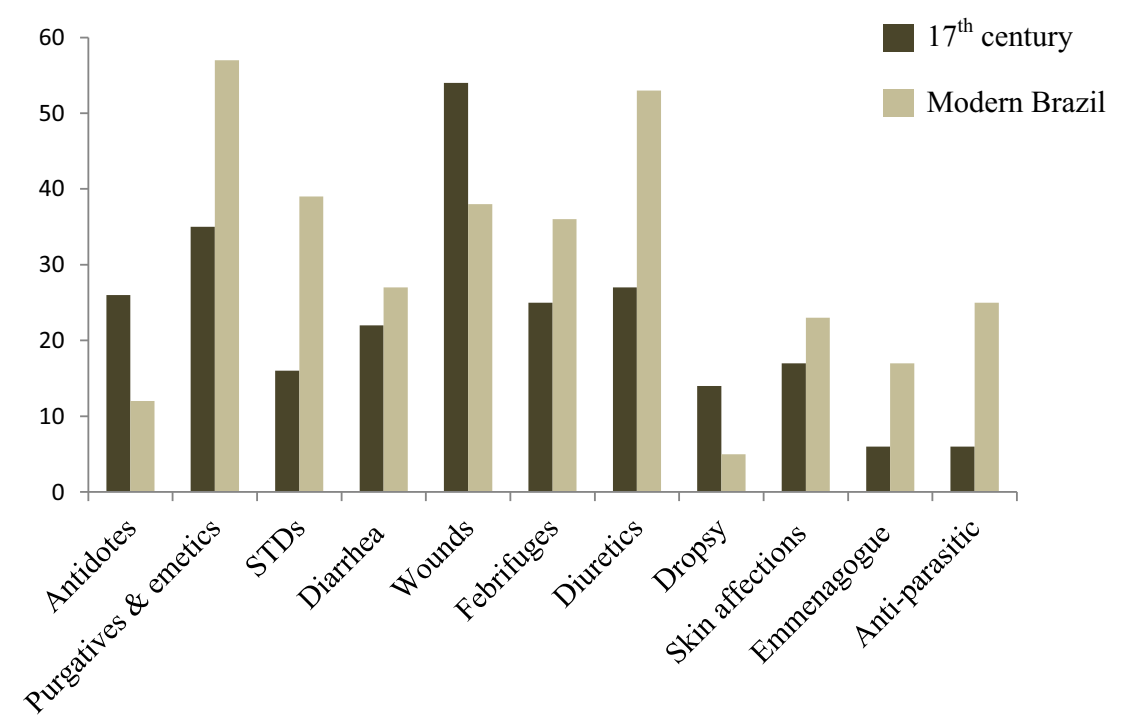

Fig. 2. Number of plant species in medicinal use categories in the seventeenth century and modern Brazil.

mentioned in the HNB. Margrave and Piso described a total of 228 combinations of plant species and health affections, while we recorded in total 413 of such combinations for modern Brazil for the same species. Several of the useful plants that we identified in the HNB are now used to treat other ailments, such as jaundice, arthritis, or neuralgia.

\section{Marcgrave's Herbarium}

On some of the pages in Marcgrave's herbarium, botanical specialists incorporated glued identification slips. For example, John J. Wurdack, curator of botany in the Smithsonian Institution, identified Clidemia biserrata in 1969 (p. 25). Other specimens, like Vismia guianensis (Aubl.) Pers. (p. 157), have labels or notes with an identification, the page number corresponding to the HNB (Marcgrave: 96), and the local name ("Caa-opia"), but the author of these labels is missing or unreadable. The bound herbarium contains 173 pages with 177 plant specimens (Fig. 3).

Four pages contain mixed collections, such as page 18 with a specimen of Zollernia latifolia Benth. with the epiphytic orchid Trigonidium acuminatum Bateman ex Lindl. On page 61, fruits of Physalis pubescens L. are combined with a twig of Rivina humilis L. There are 32 species that are collected more than once (e.g., Eichhornia paniculata (Spreng.) Solms: 26 and 27). We identified a total of 146 taxa, of which 141 to species level and five to genus level (ESM 3). We encountered 37 species that were not mentioned in the published works (e.g., Abrus precatorius L.). We found 11 species of Old World origin and 114 species in the herbarium that correlated with Marcgrave and Piso's published work $(1648,1658)$, of which $76(52 \%)$ were reported as useful. Although only names and no plant uses are written on the herbarium sheets, most of the herbarium specimens described in the HNB are medicinal $(76 \%)$, edible $(41 \%)$, or used for technology (28\%), such as Jatropha curcas L., or Ricinus communis L., of which the seed oil was used as a lamp fuel by Portuguese and Dutch settlers, but also as a medicinal oil by indigenous peoples.

Useful Species of African Origin in the HNB. The HNB also provides several examples of plant knowledge exchange between Europeans, indigenous peoples, and the enslaved Africans that were brought to Pernambuco since the beginning of the 1560s as forced labor in the sugar fields (Fausto 2014). When Piso attended to the diseases of African slaves, native peoples, and European colonists, he noticed useful herbs that had been introduced from Africa (Voeks 2013). Both Marcgrave and Piso cited African vernacular plant names, medicinal practices, as well as weeds and crops that were part of the diet of African peoples. Some of these plant species were also used by indigenous peoples, Portuguese, and Dutch settlers within the complex exchange in plant knowledge that occurred in the colonial context. 


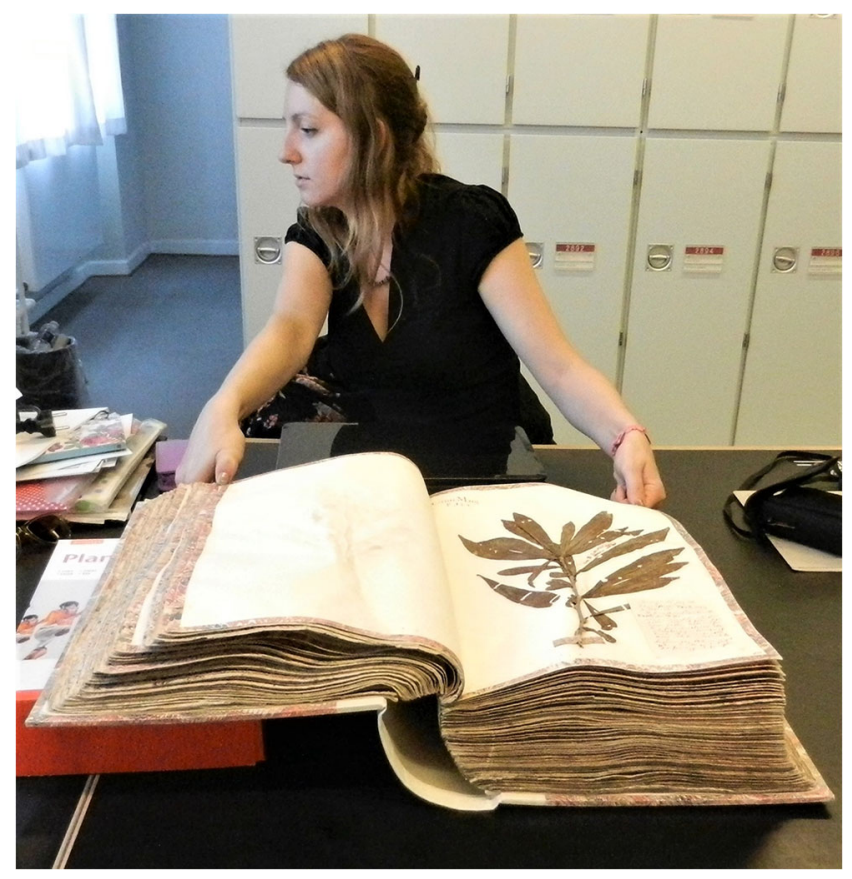

Fig. 3. Marcgrave's herbarium (p. 50), Mireia Alcantara Rodriguez showing the specimen of Crescentia cujete L. Picture taken by Tinde Van Andel (Botanical Museum of Copenhagen, July 2014).

Twenty-nine species of Old World origin (see ESM 2) were reported in Marcgrave and Piso $(1648,1658)$, such as sesame (Sesamum indicum L.), named Gangila by the "Congo people" (the term used in the HNB is "congensibus") and, according to Marcgrave (1648, p. 21), introduced from Africa by Portuguese colonizers. Other examples are the African eggplant, Solanum macrocarpon L., named Macumba by Congolese and Tongu by the "Angolese" (Marcgrave 1648, p. 24) and okra (Abelmoschus esculentus (L.) Moench), known as Quillobo (Marcgrave 1648, p. 31). Some of the plants introduced from Africa were edible weeds, such as the spider plant (Cleome gynandra L.), while others were crops brought by the European settlers from Africa to be planted in Brazil's similar tropical environment, such as banana and plantain (Musa spp.), which were initially introduced from Asia to Africa centuries before the slave trade (Kury et al. 2013).

Paintings of Dutch Brazil. Some species that figure in the paintings by Albert Eckhout and Frans Post, such as the African weed Abrus precatorius, are missing in the HNB but are present in Marcgrave's herbarium, and therefore, we consider them representative of the seventeenth century flora of NE Brazil. Other useful species of colonial
Brazil that figure in the paintings are native crops such as cassava (Manihot esculenta Crantz) and casabanana (Sicana odorifera (Vell.) Naudin) and Old World plants like coconut (Cocos nucifera L.) and banana (Musa sp.). European species introduced by the Portuguese, such as kale (Brassica oleracea L.) and turnip (Brassica napus L.), also appear on these paintings.

Phytogeographical Distribution of the HNB Species. Only one species (Swartzia pickelii Ducke) occurs exclusively in northeastern Brazil (Ferreira et al. 2019; Flora do Brasil 2016; CNC Flora 2012). Five species (Dioclea marginata, Encholirium spectabile Mart. ex Schult. \& Schult.f., Eugenia luschnathiana (O.Berg) Klotzsch ex B.D.Jacks., Licania tomentosa (Benth.) Fritsch., and Pouteria grandiflora (A.DC.) Baehni) were indicated as endemic to the northeast by some sources but had wider distribution ranges according to others (ESM 1). According to the online flora of Brazil, D. marginata is indicated as endemic to northeast Brazil, although it is also found in Paraná, south of Brazil (http://www.splink.org.br/index?lang=en). The seeds of other Dioclea species are used elsewhere in Brazil to obtain flour to prepare arepas (Maxwell 2011), a flat bread, normally made of maize, originating in Venezuela and Colombia, but also eaten in Brazil. Although Marcgrave reported D. marginata as an edible plant 
"prepared like cassava" (probably the seeds were ground to make flour), we are not certain, which species of Dioclea are ground into flour in Brazil today. E. spectabile is mentioned as endemic to northeast Brazil by the online flora, but it is also found in Minas Gerais (southeast) (http://www.tropicos.org/Specimen/3003066). E. luschnathiana used to be endemic to northeast Brazil, but it has been recently introduced and naturalized in Florida (Lucena et al. 2014). L. tomentosa is described by Ferreira et al. (2019) as endemic to northeast Brazil, but this species is found in other regions of the country according to the online flora and the Species Link online database. P. grandiflora was listed by the online flora as endemic to the northeast, and in Tropicos, most of the specimens were collected in Bahia and Sergipe (northeast), but some were found in Espírito Santo (Southeast) and in the Darien gap in Panamá. Swartzia pickelii is the only useful species described in the HNB that is considered endemic to northeast Brazil by all consulted sources. According to Piso, its fruit pulp was edible when cooked (ESM 1). Today, the wood of this tree is used in Pernambuco for production of fuel and construction, and the stem to make brooms (Silva 2008), but the fruit is no longer consumed.

\section{Discussion}

\section{Historia NatuRalis SEPTENTRIONALES OR BRASILIAE?}

Although compiled in northeast Brazil, the HNB was presented as an encyclopedia of Natural History of the entire country and also perceived as such by European scholars of the Early Modern period. But to which extent does the HNB represent the specific situation in the northeastern part of the country? Our ethnobotanical analysis shows that with regard to useful plants, the HNB is far more representative for the entire country than one might expect. From all the useful species described in the HNB, only Swartzia pickelii is endemic to the Caatinga or Atlantic Rainforest biomes where Marcgrave and Piso conducted their expeditions (Gardner 1846). The majority of the plants are much more widespread, encompassing the diverse biomes of Brazil. Many species of useful plants documented in the HNB (e.g., cashew, cassava, Bixa orellana L., Xanthosoma sagittifolium (L.) Schott) were, and are, used similarly by many indigenous groups throughout Brazil (Corrêa 1926-1975; Schoof
2012). In addition, there is evidence of ample migration patterns of the Tupi-speaking people whose knowledge was documented in the HNB, before and increasingly after the Dutch colonization of Brazil (Monteiro 1999; Neves et al. 2011). Therefore, the plant knowledge recorded in the HNB could have been preserved in different locations occupied over time by the descendants of indigenous peoples who migrated out of northeast Brazil in the past centuries.

The origin and transmission of ethnobotanical knowledge in the different regions of Brazil has not been studied extensively. Unlike Leonti (2011), who traced the influence of ancient Greek and Roman herbals in modern Europe, we cannot trace back the influence of the written account in the HNB in the local Brazilian pharmacopeias, because this book was only accessible for literate European elites (including doctors, scholars, and religious people) in the Early Modern period. It only became widely available in Brazil in the twentieth century, when it was translated into Portuguese, and it is very dubious that it ever influenced the indigenous Tupi-speakers and African descendants, from whom this plant knowledge was appropriated. The oral transmission of plant selection and botanical knowledge between ethnic groups is more likely than a causal influence of the HNB in the Brazilian pharmacopeia. In any case, plant uses described in the HNB are now representative of larger territories in Brazil.

\section{Retention of Seventeenth-Century Plant Use in Mod- ern Brazil}

Most of the useful flora reported in the two versions of the HNB were employed for medicine and food. Medicinal species were the largest category in both the seventeenth century and today, increasing in importance over time. Food, on the other hand, was the second largest category in 1648 , but the number of reported edible species is reduced today. We still found a higher number of edible species than Medeiros and Albuquerque (2014), who missed 32 edible species documented by Marcgrave (1648) (e.g., Cereus fernambucensis Lem., Ficus gomelleira Kunth \& C.D.Bouché) and another 16 food species from Piso (1658), such as Lagenaria siceraria (Molina) Standl. and Macoubea guianensis Aubl. Marcgrave's original herbarium proved to be very relevant to identify several species described in the HNB. For 22 food species, we obtained different taxonomical identifications than 
Medeiros and Albuquerque (2014), of which at least four edible species (Cecropia pachystachya Trécul, Spondias mombin L., Physalis pubescens, and Clidemia biserrata) were included in Marcgrave's herbarium. We also encountered 24 more plant species in the herbarium that correlated with the work of Marcgrave and Piso $(1648,1658)$ than Andrade-Lima et al. (1977), who probably checked only Marcgrave's text from 1648 and reported only 90 corresponding species.

There was a slight difference in the percentage of edible species between the HNB and modern Brazil ( 48 vs. $44 \%$ ), in which 28 of the 124 edible species from the HNB are no longer consumed in Brazil today, such as Copernicia prunifera (Mill.) H.E.Moore and Ficus gomelleira. On the other hand, some species that were described as medicinal in the past are now part of the Brazilian diet, such as Piper marginatum Jacq. or Senna occidentalis (L.) Link. The decrease in edible plants over time can be related to changes in perceptions about food and recipes since the seventeenth century and demographic changes of the population who consumed these food resources, mostly Tupi-speaking indigenous peoples. As those peoples migrated to other areas, they must have adjusted their plant-based diet to the new environment. According to Medeiros and Albuquerque (2014), the number of food plants in seventeenth-century Brazil was higher than today due to modern cultural taboos that consider these ancient food resources as a sign of poverty. However, Senna occidentalis was not reported in the $\mathrm{HNB}$ as an edible plant, but its seeds are roasted as coffee by Brazilians in the northeastern region of Ceará (Lombardo et al. 2009) and in other parts of Brazil (Lorenzi and Matos 2008). Montrichardia arborescens (L.) Schott was an "edible fruit in case of need" (Marcgrave 1648; Piso 1648, 1658), and its fruits are still sporadically eaten today (Schoof 2012). This trend was also reported for eighteenth-century food plants in Suriname, where $M$. arborescens was consumed by runaway slaves without other food sources, but nowadays only used as fish bait (Andel et al. 2012). The species Ananas comosus (L.) Merr., Bixa orellana, Canna glauca L., Carica papaya L., Syagrus coronata (Mart.) Becc., and Xylopia frutescens Aubl. were not categorized as food in modern Brazil by Medeiros and Albuquerque (2014), but they are still commonly consumed (A. comosus, B. orellana, and C. papaya) or occasionally eaten in Brazil ( $C$. glauca, S. coronata, and $X$. frutescens) (Mors et al. 2000). Our comparison shows the continuation, to some extent, of vegetable food resources over time. However, some commonly eaten plants in the seventeenth century, such as Spondias tuberosa Arruda and Amaranthus viridis L. had already turned into "emergency food" in the 1920s (Correia 1926-1975), as was also reported for eighteenth-century food plants in Suriname (van Andel et al. 2012).

Transformations in Medicinal Plant Use over Time. The European colonial pharmacopeia was strongly influenced by the input of knowledge acquired from native Brazilians (Carneiro 2011). Several food and medicinal species were incorporated into European Materia Medica, such as Anacardium occidentale L. (Albuquerque et al. 2007) and Passiflora edulis Sims (Cartaxo et al. 2010). Indigenous peoples had a good reputation as healers through the use of wild and cultivated plants (Mors et al. 2000). However, many more species are presently recorded in Brazil today for their therapeutic properties than the 171 medicinal species documented in the HNB. Medicinal plant trade has taken place in Brazil since the Portuguese Jesuits started it in the sixteenth century (Walker 2013), promoting a diffusion of knowledge not only toward Portugal, but also to diverse regions of the country and to the Portuguese Empire. Nowadays, a wide variety of medicinal plants is used in Brazil, in both urban and rural areas (Rates 2001). Taking into account that our literature review covered a larger region than the territories explored by Marcgrave and Piso, the higher number of medicinal plants could be related to the increase in the last decades in ethnobotanical studies (Albuquerque et al. 2007; Bieski et al. 2012; Cartaxo et al. 2010; Coelho-Ferreira 2009; Corrêa 1926-1975; Lorenzi 1998; Lorenzi and Matos 2008) or the recent phytomedicinal development promoted by Brazil's great floristic diversity and potential for natural drug production (Calixto 2005). On the other hand, local pharmacopeias have changed, and some traditional medicines have been replaced by synthetic products while other uses may have been forgotten.

Most of the plant species documented by Marcgrave and Piso kept their function and their use was often extended to other categories. Cascabela thevetia (L.) Lippold was powdered and mixed with tobacco or food to produce its highly toxic effects (Piso 1648, p. 49), while in the twentieth century, it was still considered as a paralyzing poison, but mainly planted as an ornamental (Corrêa 1926). Other medicinal plants from the HNB treat different ailments today than in the past. The resin and oil squeezed from Schinus molle L. was used as poultice for cold affections: "The tree's astringent and warm leaves are used in baths, both to heal the body and to obtain pleasure" (Piso 1648, p. 64). Piso based his 
terminology on the hot-cold Hippocratic humoral theory that still prevailed in the seventeenth century, prescribing warm plants to heal cold diseases and vice versa. S. molle oil was later indicated for corneal diseases and tumors arising from arthritis or syphilis, while leaves were used against rheum, ulcers, and wounds (Corrêa 1926-1975). Plants that were once used to heal skin ulcers and wounds have now been replaced by antibiotics and antiseptic creams. Brazilians use fewer plants as antipoison treatments today, despite the high occurrence of snakebites, a serious public health issue, especially in rural areas (Feitosa et al. 2015). The observed transformations in medicinal use can be explained by changes in the perception of health and illness since the development of modern medicine and the introduction of new terms for diseases since 1648 (van Andel et al. 2012).

Still, some ideas on human health and diseases have persisted over time. In the nineteenth century, naturalists and physicians Piotr Czerniewicz, George Gardner, and Auguste de Saint-Hilaire depicted several plants to heal human ailments based on their expeditions to Brazil (Chernoviz 1897; Gardner 1846; SaintHilaire 1824). The ethnobotanical analysis of their manuscripts showed that diuretic, purgative, and febrifuge plants were, two centuries later, the most common ones in Brazil (Brandão et al. 2012; Fagg et al. 2015; Ricardo et al. 2017). More recently, purgative and diuretic plants have become very popular among modern Brazilians, acting as blood purifiers and intestinal cleansings (Bieski et al. 2012; Coelho-Ferreira 2009). The retention of these particular plant uses may be related to attempts to achieve modern beauty standards and weight loss with purgatives, which is a common practice among young Brazilians (Kakeshita et al. 2013; Nunes et al. 2003).

Despite the observed trends in plant use over time, Marcgrave and Piso may not have properly documented all plant species and local diseases in Dutch Brazil. Access to specific areas was certainly a challenge for these two scholars, not exempt from hostile encounters, water supply limitations, and other difficulties in the tropical territory (Van den Boogaart and Brienen 2002). Moreover, understanding as well as respecting indigenous peoples' cosmologies and cosmovision was probably not considered or valued by Marcgrave and Piso. Their personal bias likely influenced their work, as the background of both authors and their editor developed within a particular European context, highly influenced by the dominant political and religious scene at that time (Furtado 2007). During his enquiries, Piso explicitly expressed both rejection and praise to indigenous medical practices that did not fall into the medical mainstream: "How among such crass barbarism many gross or corrupt practices, unworthy of Hippocratic art, are encountered, so that not a few very useful ones, which smell of antiquity, can be observed, and that foreign doctors who are well versed in art submit to discipline" (Piso 1648, p. 15).

In Early Modern Europe, it was common to eliminate evidence of abortive and ritual plant uses documented by European explorers, due to religious beliefs, gender attitudes, and social constraints in western society (Schiebinger 2009). Although European scientists incorporated a great corpus of indigenous knowledge to create the HNB, they must have missed or deliberately left out certain plant uses. In addition, native peoples or enslaved Africans who were compelled, to a greater or lesser degree, to give full information on their plant resources to European colonists could have been reluctant to do so and therefore have chosen to conceal information. Finally, the great number of useful plants encountered in our literature survey is a result of the large percentage of Brazil that is now covered by modern ethnobotanical research, compared to the small northeastern region that was explored in the seventeenth century by Marcgrave and Piso. Further ethnobotanical field research in northeast Brazil in cooperation with Tupi-speaking indigenous peoples and other ethnic groups is needed to bring new insights on plant knowledge retentions since colonial Dutch Brazil and to co-produce data, ideas, and methods that benefit all the stakeholders.

\section{Conclusions}

Marcgrave and Piso depicted the rich flora and its many uses by the different ethnic groups who coexisted in northeastern Brazil in 1648 in their influential work of early modern science, the Historia Naturalis Brasiliae. Most species depicted in the HNB (68\%) have one or more uses by the indigenous population, European settlers, and/or enslaved Africans, while $80 \%$ of these useful species are used in different regions of Brazil in a similar way as in seventeenth-century Dutch Brazil. A substantial number of Old World plants, introduced during the trans-Atlantic slave trade, were used by enslaved Africans, indigenous peoples, and Europeans. The HNB provides evidence for early plant dispersal by 
the Portuguese and the Dutch via the Middle Passage and the exchange of African ethnobotanical knowledge with other inhabitants in seventeenthcentury Brazil. We encountered higher numbers of Brazilian medicinal plant uses in the recent literature, used for a wider spectrum of diseases than were reported in the $\mathrm{HNB}$, but this is probably due to the development of ethnobotanical surveys in the country in the past century, compared to the small northeastern region that was explored in the seventeenth century by Marcgrave and Piso.

Our analysis shows that only a very small number of the useful plants documented in the HNB are endemic to the northeast. Most species occur in other regions of the country and uses described in the HNB are representative for larger parts of Brazil. We found fewer edible plants in modern sources than in 1648, which could be explained by changes in diet and health perceptions over time. However, some of these differences could also be the result of the editing process or the research methodology used by the authors of the HNB. By comparing the Historia Naturalis Brasiliae with current plant uses in Brazil, we can observe how indigenous and African plant knowledge has been preserved over time. This local knowledge influenced the works of scholars over the past 370 years, but it is time to critically look into its content and enhance awareness on the crucial role of its non-European contributors.

\section{Acknowledgments}

We kindly thank the curator of the Botanical Museum of Copenhagen, Prof. Dr. Ib. Friis, for providing us access to the well-conserved Marcgrave's herbarium and for his hospitality and attention. We strongly thank all the botanists, librarians, and administrative staff of the Naturalis Herbarium in Leiden, especially Prof. Dr. Paul Maas and the collection manager Roxali Bijmoer, for their logistic support and floristic expertise.

\section{Funding Information}

This study was funded by Alberta Mennega Stichting and Naturalis Biodiversity Center and the European Research Council (ERC) Horizon 2020 Research and Innovation Programme (Grant Agreement No. 715423), ERC Project BRASILIAE: Indigenous Knowledge in the Making of Science, directed by Dr. M. Françozo at Leiden University.
Open Access This article is distributed under the terms of the Creative Commons Attribution 4.0 International License (ht t p: / / creativecommons.org/licenses/by/4.0/), which permits unrestricted use, distribution, and reproduction in any medium, provided you give appropriate credit to the original author(s) and the source, provide a link to the Creative Commons license, and indicate if changes were made.

\section{Literature Cited}

Albertin, P. J. 1985. Arte e Ciência no Brazil Holandês. Theatri Rerum Naturalium Brasiliae. Revista Brasileira de Zoologia 3(5): 249-326.

Albuquerque, U. P., P. M. De Medeiros, A. L. S. De Almeida, J. M. Monteiro, E. M. F. L. Neto, J. G. De Melo, and J. P. Dos Santos. 2007. Medicinal plants of the caatinga (semi-arid) vegetation of NE Brazil: A quantitative approach. Journal of Ethnopharmacology 114(3): 325-54. Almeida, A. V. 2008. Flora do Nordeste do Brasil segundo Piso e Marcgrave no século XVII. (Bento José Pickel 1949). Recife: EDUFRPE.

Andrade-Lima, D., A. F. Maule, T. M. Pedersen, and K. Rahn. 1977. Marcgrave's Brazilian Herbarium, collected 1638-44. In: Botanisk tidsskrift - Biodiversity Heritage Library, 121160.

Bennet, B. C. and G. T. Prance. 2000. Introduced plants in the indigenous pharmacopoeia of northern South America. Economic Botany 54: 90-102.

Bieski, I. G. C., F. R. Santos, R. M. De Oliveira, M. M. Espinosa, M. Macedo, U. P. Albuquerque, and D. T. O. Martins. 2012. Ethnopharmacology of medicinal plants of the Pantanal region (Mato Grosso, Brazil). Evidence-Based Complementary and Alternative Medicine. https://doi.org/10. 1155/2012/272749.

Bioportal Naturalis Biodiversity Center. Browse Dutch natural history collections. 2019. http:// bioportal.naturalis.nl/. (February 2019).

Boeseman, M. 1994. A hidden early source of information on north-eastern Brazilian zoology. Zoologische Mededelingen Leiden 68(12): 113125.

Bontius, J. 1642. De medicina Indorum. Franciscus Hackius Leiden. 
Brandão, M. G., M. Pignal, S. Romaniuc, C. F. Grael, and C. W. Fagg. 2012. Useful Brazilian plants listed in the field books of the French naturalist Auguste de Saint-Hilaire (17791853). Journal of Ethnopharmacology 143(2): 488-500.

Buvelot, Q., D. T. Martins, E. De Vries, F. Egmond, and P. Mason. 2004. Albert Eckhout: A Dutch artist in Brazil. Mauritshuis, The Hague.

Calixto, J. B. 2005. Twenty-five years of research on medicinal plants in Latin America. A personal view. Journal of Ethnopharmacology 100:131-134.

Carneiro, H. 2011. O saber fitoterápico indígena e os naturalistas Europeos. Fronteiras 13(23): 13-32.

Cartaxo, S. L., M. M. D. A. Souza, and U. P. Albuquerque. 2010. Medicinal plants with bioprospecting potential used in semi-arid northeastern Brazil. Journal of Ethnopharmacology 131(2): 326-42.

Catalogue of Life: 2018 Annual Checklist. 2018. Indexing the world's known species. http:// www.catalogueoflife.org/annual-checklist/2018/ . (January 2019).

Chernoviz, P. L. N. 1897. Formulário e Guia Médico, 16th ed. Paris: A. Roger and F. Chernoviz.

CNC Flora. 2012. Lista Vermelha da flora brasileira. Centro Nacional de Conservaçáo da Flora. http://cncflora.jbrj.gov.br/portal. (January 2019).

Coelho-Ferreira, M. 2009. Medicinal knowledge and plant utilization in an Amazonian coastal community of Marudá, Pará State (Brazil). Journal of Ethnopharmacology 126(1): 159-175.

Cook, H. J. and S. Dupré. 2013. Translating knowledge in the Early Modern Low Countries. Münster: LIT Verlag.

Corrêa, P. M. 1926-1975. Dicionário das plantas úteis do Brasil e das exóticas cultivadas. Rio de Janeiro: Imprensa Nacional.

Correia, A. 1948. História Natural do Brasil, Edição comemorativa. São Paulo: Editora Nacional.

De Quesada, F. X. 1615. Rerum medicarum Novae Hispaniae the-saurus; seu, Plantarum, animalium, mineralium, mexicanorum historia. Mexico.

Eltis, D. and D. Richardson. 2010. Atlas of the transatlantic slave trade. New Haven: Yale University Press.

Fagg, C. W., E. N. Lughadha, W. Milliken, D. N. Hind, and M. G. Brandão. 2015. Useful Brazilian plants listed in the manuscripts and publications of the Scottish medic and naturalist George
Gardner (1812-1849). Journal of Ethnopharmacology 161: 18-29.

Fausto, B. 2014. A concise history of Brazil. Cambridge: University Press.

Françozo, M. 2010. Alguns comentários à Historia Naturalis Brasiliae. Cadernos de Etnolingüística 2(1): 1-7.

Feitosa, E. S., V. Sampaio, J. Sachett, D. B. De Castro, M. D. N. Noronha, J. L. L. Lozano, E. Muniz, L. C. L. Ferreira, M. V. G. De Lacerda, and W. M. Monteiro. 2015. Snakebites as a largely neglected problem in the Brazilian Amazon: Highlights of the epidemiological trends in the State of Amazonas. Revista da Sociedade Brasileira de Medicina Tropical 48(1): 34-41.

Ferreira, D. M. C., B. S. Amorim, J. R. Maciel, and M. Alves. 2019. Floristic checklist from an Atlantic Forest vegetation mosaic in Reserva Particular do Patrimônio Natural Fazenda Tabatinga, Pernambuco, Brazil. Check List 12(6): 18. https://doi.org/10.15560/12.6.2019.

Flora Brasiliensis. The Project. 2005. Flora Brasiliensis, eds. C. F. P. Von Martius, A. W. Eichler, and I. Urban. 1840-1906. http:// florabrasiliensis.cria.org.br. (January 2019).

Flora do Brasil 2020 under construction. 2016. Jardim Botânico do Rio de Janeiro. http:// floradobrasil.jbrj.gov.br. (February 2019).

Freyre, G. 1989. Aspectos da influência da cana sobre a vida e a paisagem do Nordeste do Brasil, 6th ed. Rio de Janeiro: Editora Record.

Furtado, J. F. 2007. Tropical empiricism: Making medical knowledge in colonial Brazil. In: Science and empire in the Atlantic World, eds. J. Delbourgo and N. Dew, 141-166. New York: Routledge.

Gardner, G. 1846. Travels in the Interior of Brazil, principally through the northern provinces, and the Gold and Diamond districts, during the years 1836-1841. London: Reeve Brothers.

Gudger, E.W. 1912. George Marcgrave, the first student of American Natural History. Popular Science Monthly 81: 250-274.

Kakeshita, I. S., M. F. Laus, and S. S. Almeida. 2013. Living well but looking good: A modern health dichotomy: a brief overview on women's body image. Revista de Educação Física 19(3): 558-564.

Kury, L., H. M. Gesteira, B. M. B. Leite., F. C. Edler, L. M. Algranti, and J. R. Apolinário. 2013. Usos e circulação de plantas no Brasil: séculos XVI a XIX. Rio de Janeiro, RJ: Andrea Jakobsson Estúdio. 
Langfur, H. 2014. Native Brazil: Beyond the convert and the cannibal, 1500-1900. Albuquerque: University of New Mexico Press.

Leonti, M. 2011 The future is written. Impact of scripts on the cognition, selection, knowledge, and transmission of medicinal plant use and its implications for ethnobotany and ethnopharmacology. Journal of Ethnopharmacology 134(3): 542-555.

Lombardo, M., S. Kiyota and T. M. Kaneko. 2009. Aspectos étnicos, biológicos e químicos de Senna occidentalis (Fabaceae). Revista de Ciências Farmacêuticas Básica e Aplicada 30(1): 9-17.

Lorenzi, H. 1998. Árvores brasileiras: Manual de identificaçáo e cultivo de plantas arbóreas nativas do Brasil, Vol. 2. Nova Odessa, Sáo Paulo: Plantarum.

Lorenzi, H. and F. J. A. Matos. 2008. Plantas medicinais no Brasil: Nativas e exóticas, 2nd ed., Nova Odessa, São Paulo: Plantarum.

Lucena, E. M. P., R. E. Alves, L. Cisneros-Zevallos, E. W. Moraes-Luz, and E. S. Brito. 2014. Biodiversidade das Myrtaceae Brasileiras adaptadas à Flórida, EUA. Revista Brasileira de Geografia Física 7(2): 327-340.

Marcgrave, G. 1942 [1648]. História natural do Brasil. Translated by José Procópio de Magalhães. São Paulo: Imprensa Oficial do Estado.

Marcgrave, G. and W. Piso. 1648. Historia naturalis Brasiliae: in qua non tantum plantæ et animalia, sed et indigenarum morbi, ingenia et mores describuntur et iconibus supra quingentas illustrantur. Amsterdam: Elsevier.

Maxwell, R. H. 2011. New species and notes in the genus Dioclea s.l. (Fabaceae, subtribe Diocleinae). Novon: A Journal for Botanical Nomenclature 21(2): 226-243.

Medeiros, M. F. T. and U. P. Albuquerque. 2014. Food flora in seventeenth century Northeast region of Brazil in Historia Naturalis Brasiliae. Journal of Ethnobiology and Ethnomedicine 10(1): 50.

Ministério da Educação e Saúde. 1962. Índice dos anais da Biblioteca Nacional. Rio de Janeiro: Divisão de Obras Raras e Publicações.

Monardes, N. B. 1574. De simplicibus medicamentis ex occidentali India delatis quorum in medicina usus est. Antwerp: Plantin.

Monteiro, J. M. 1999. The crises and transformations of invaded societies: Coastal Brazil in the sixteenth century. In: The Cambridge History of the Native Peoples of the Americas, eds. F.
Salomon and S. B. Schwartz, 973-1024. Cambridge: Cambridge University Press.

Mors, W. B., C. T. Rizzini, and N. A. Pereira. 2000. Medicinal plants of Brazil. Michigan: Reference Publications.

Neves, W. A., D. V. Bernardo, V. Danilo, M. Okumura, T. F. Almeida, and A. M. Strauss. 2011. Origem e dispersão dos Tupiguarani: $\mathrm{O}$ que diz a morfologia craniana? Boletim do Museu Paraense Emílio Goeldi. Ciências Humanas 6(1): 95-122.

Nunes, M. A., F. C. Barros, M. A. Olinto, S. Camey, and J. D. J. Mari. 2003. Prevalence of abnormal eating behaviors and inappropriate methods of weight control in young women from Brazil: A population-based study. Eating and Weight Disorders-Studies on Anorexia, Bulimia and Obesity 8(2): 100-106.

Piso, W. 1948 [1648]. História natural do Brasil. São Paulo: Imprensa Oficial do Estado.

1658. De India Utriusque Re Naturali et Medica. Amsterdam: Elsevier.

Prance, G. T., W. Balee, B. M. Boom, and R. L. Carneiro. 1987. Quantitative ethnobotany and the case for conservation in Amazonia. Conservation Biology 1(4): 296-310.

Rates, S. M. K. 2001. Plants as source of drugs. Toxicon 39(5): 603-613. https://doi.org/10. 1016/S0041-0101(00)00154-9.

Ricardo, L. M., J. D. Paula-Souza, A. Andrade, and M. G. Brandão, M. G. 2017. Plants from the Brazilian Traditional Medicine: Species from the books of the Polish physician Piotr Czerniewicz (Pedro Luiz Napoleão Chernoviz, 1812-1881). Revista Brasileira de Farmacognosia 27(3): 388400.

Rodrigues, A. D. 1994. Línguas Brasileiras: Para o conhecimento das línguas indígenas. São Paulo: Ediçôes Loyola.

Rogers, T. D. 2010. The deepest wounds. A labor and environmental history of sugar in Northeast Brazil. Chapel Hill: University of North Carolina Press.

Romero-Reverón, R. and L. A. Arráez-Aybar. 2015. Ole Worm (1588-1654)—Anatomist and antiquarian. European Journal of Anatomy 19(3): 299-301.

Safier, N. F. 2014. Beyond Brazilian Nature: The Editorial Itineraries of Marcgraf and Piso's Historia Naturalis Brasiliae. In: The Legacy of Dutch Brazil, ed. M. Van Groesen, 168-186. Cambridge: Cambridge University Press. https://doi.org/10.1017/ CBO9781107447776.011 
Saint-Hilaire, A. 1824. Plantes usuelles des Brésiliens [Brazilian useful plants]. Paris: Grimbert Libraire.

Santos, C. F. M., P. R. De Lima, and R. D. Campos. 2010. A natureza do Brasil Holandês: Piso, Marcgrave e uma História natural do Brasil ilustrada. In: História Das Ideias: Viajantes, Naturalistas E Ciências Na Modernidade, ed. C. F. M. Santos, 33-58. Maringá: Eduem Editora da Universidade Estadual de Maringá. Maringá.

Schiebinger, L. L. 2009. Plants and empire: Colonial bioprospecting in the Atlantic World. Cambridge, Massachusetts: Harvard University Press.

Schoof, L. 2012. Ervas: Uso e cultivo. Guia para o mundo maravilhoso das plantas. Unpublished manuscript, information is digitally available at website: http://avicena.nl/avicena_br.htm (January 2019).

Silva, A. L. S. 2008. Flora da Fazenda Morim, São José da Coroa Grande, Pernambuco, Brasil. $\mathrm{PhD}$ thesis. Flora da Fazenda Morim, São José da Coroa Grande, Pernambuco, Brasil.

Souza, O. M. F. 2006. Georg Marcgraf - o primeiro herborizador do Brasil. Anais da Academia Pernambucana de Ciência Agronômica, Recife 3: 25-29.

Species Link. Desde 2002. CRIA. 2019. http:// www.splink.org.br/. (January 2019).

The Plant List. 2013. A working list of all plant species. http://www.theplantlist.org. (January 2019).
Tropicos. 2019. Missouri Botanical Garden. http:// www.tropicos.org/. (January 2019).

Van Andel, T. R., P. Maas, and J. Dobreff. 2012. Ethnobotanical notes from Daniel Rolander's Diarium Surinamicum (1754-1756): Are these plants still used in Suriname today? Taxon 61: 852-863.

Van den Boogaart, E. and R. P. Brienen. 2002. Brasil Holandês. Informaçóes do Ceará de Georg Marcgraf (junho-agosto de 1639). Rio de Janeiro: Index Editora.

Voeks R. A. 2013. Ethnobotany of Brazil's African Diaspora: The role of floristic homogenization. In: African ethnobotany in the Americas, eds. R. A. Voeks and J. Rashford, 395-416. New York: Springer. https://doi.org/10.1007/978-1-46140836-9_14.

Walker, T. D. 2013. The medicines trade in the Portuguese Atlantic World: Acquisition and dissemination of healing knowledge from Brazil (c. 1580-1800). Social History of Medicine 26(3): 403-431.

Whitehead, P. J. P. 1979. The biography of Georg Marcgraf (1610-1643/4) by his brother Christian, translated by James Petiver. Journal of the Society for the Bibliography of Natural History 9: 301-314.

Whitehead, P. J. P and M. Boeseman. 1989. A portrait of Dutch seventeenth century Brazil. Animals, plants and people by the artists of Johan Maurits of Nassau. Amsterdam: NorthHolland Publishing Company. 